\title{
Re-emergence of the Glossy Ibis (Plegadis falcinellus) in inland South Korea
}

Sang-Yeon Lee ${ }^{1,2}$, Ha-Cheol Sung ${ }^{2}$, Donguk Han ${ }^{3 *}$ and Jin-Yeol Cha ${ }^{1 *}$

\begin{abstract}
Glossy Ibis (Plegadis falcinellus), which has never been recorded in South Korea, appeared on Jeju Island in 2018 and re-emerged in the inland area of Seocheon-gun (South Chungcheong Province) and in Goyang-si (Gyeonggi Province) in the following year. This study aims to report the progress in observing $P$. falcinellus in the inland areas of South Korea in 2019 and to predict its origin region and future propensity for habitats in the country through literature review. On 5 May 2019, an individual of P. falcinellus with breeding feathers was observed in a farmland in Wolsan-ri, Seocheon-gun. Twelve days later, another one was identified in a farmland in Janghang-dong, Goyang-si, about $173 \mathrm{~km}$ north of Wolsan-ri. The observed birds fed and rested in the area and stayed for only a day. The individual birds spotted in South Korea in 2019 are conjectured to have come from either Southeast Asia or Australia, among areas located in East Asian-Australasian Flyway (EAAF). This is because P. falcinellus, a species with excellent dispersal capacity, forms a population in new areas during extreme environmental changes in their current habitats, especially droughts. For 2 years, P. falcinellus was observed to be migrating in spring; however, in the future, they may exhibit the same propensity for breeding and habitats as that of birds migrating in autumn. As it is a conspicuous species, effective detection of their arrival requires a survey system that classifies the country by habitat type and involves periodic and multiple observations by experts and citizens.
\end{abstract}

Keywords: Dispersal, Plegadis falcinellus, Propensity, Re-emergence, Rice field, South Korea

\section{Background}

There are 36 species of Threskiornithidae, including ibises and spoonbills (Gill and Donsker 2019). The Glossy Ibis ( $P$. falcinellus) is among the smaller species at about $60 \mathrm{~cm}$ in length and weighing approximately $650 \mathrm{~g}$ (Hancock et al. 1992). It is found on all continents, except Antarctica (Matheu and del Hoyo 1992; Hagemeijer and Blair 1997; Davis Jr. and Kricher 2000; Figuerola et al. 2004; Clobert et al. 2012; Gill and Donsker 2019), thereby demonstrating fragmented distribution (Birdlife International 2019). P. falcinellus is a type of wader (Santoro 2019), which is a biomarker group sensitive to global environmental changes. It is a least concern (LC) species on the International Union

\footnotetext{
* Correspondence: ecogideuk@gmail.com; trycha77@nie.re.kr

${ }^{3}$ PGA Eco and Bio Diversity Institute, Eco Korea, 139-43, Daeju-ro 107beon-gil, Deogyang-gu, Goyang 10456, South Korea

'Division of Ecological Survey, National Institute of Ecology, 1210,

Geumgang-ro, Maseo-myeon, Seocheon 33657, South Korea

Full list of author information is available at the end of the article
}

for Conservation of Nature (IUCN) Red List. Moreover, it is a protected species under the African-Eurasian Migratory Waterbird Agreement (AEWA) and is listed in Annex II of the Convention on Migratory Species (CMS). However, its population is in decline on a global scale (Birdlife International 2019).

The Stork, Ibis, and Spoonbill Specialist Group (SISSG), one of the 18 bird specialist groups in IUCN, which was founded in 1981, has 97 specialists over five continents (Rodríguez 2019). The SIS-SG published the SIS Conservation Journal in 2019 to disseminate information on the conservation and management of population ecology and habitats of SIS distributed across the world. The theme of the first issue is the ecology and conservation of Glossy Ibis (Plegadis falcinellus), thus implying its significance (Gopi-Sundar and Cano-Alonso 2019).

Compared to other bird species, P. falcinellus is nomadic, thereby making its ecological research difficult (Hancock et al. 1992; Zwarts et al. 2009; Santoro et al.

(c) The Author(s). 2020 Open Access This article is licensed under a Creative Commons Attribution 4.0 International License, which permits use, sharing, adaptation, distribution and reproduction in any medium or format, as long as you give appropriate credit to the original author(s) and the source, provide a link to the Creative Commons licence, and indicate if changes were made. The images or other third party material in this article are included in the article's Creative Commons licence, unless indicated otherwise in a credit line to the material. If material is not included in the article's Creative Commons licence and your intended use is not permitted by statutory regulation or exceeds the permitted use, you will need to obtain permission directly from the copyright holder. To view a copy of this licence, visit http://creativecommons.org/licenses/by/4.0/ 
2013; Santoro et al. 2016; Santoro 2019). P. falcinellus was breeding in Morocco and Algeria in North Africa until the nineteenth century (Thévenot et al. 2003). After no confirmation on its breeding for nearly a century, it has been reconfirmed in Morocco since the 1980s and in Algeria since 1998 (Nedjah et al. 2019; Nefla et al. 2019). In Europe, the species was breeding in the southern Italian island and the Sardinia islands in the central Mediterranean region until the early 1980s (Grussu 2019). After a hiatus of about a decade, it began colonization in the Spanish Donãna National Park located on the Iberian Peninsula in the western Mediterranean region in 1996 (Figuerola et al. 2004). Another colonization occurred in Camargue in southern France in 2006 (Champagnon et al. 2019).

Meanwhile, in Asia, P. falcinellus inhabits mostly the Middle East and Southeast Asia (Matheu and del Hoyo 1992; Eaton et al. 2016; Lee et al. 2018). In Northeast Asia, it is a known vagrant, which emerges occasionally (Brazil 2009). In Japan, there are official records of observations from Tokashiki Island and Kin-cho in Okinawa in 2014 (Morita et al. 2014; Miyajima et al. 2015). In China, it has been observed intermittently since 2009 in the Yunnan Province, adjacent to Myanmar and Laos; in 2019, its breeding was confirmed in Hanzhong, Shaanxi, where there had not been a single observation before (available on https://news.cgtn.com/news/2019-07-25/Rare-glossyibis-eggshells-found-in-NW-China-IBRMov4A9O/index. html). In South Korea, unlike Japan and China, there was no record of $P$. falcinellus, but in 2018, three individuals were first identified in the Yongsu-ri wetland in Hankyung-myeon, Jeju (Kang et al. 2019). Jeju is the southernmost region of South Korea, with China to its west and Japan to its east, and thus is on the bird migration route, making it a location where various bird species make an appearance (Oh et al. 2010; Kim et al. 2011). Therefore, it is difficult to determine whether the P. falcinellus individuals appearing in Jeju were simply lost after deviating from their path or whether they have expanded their area. The re-emergence of P. falcinellus in 2019 in Seocheon-gun of the South Chungcheong Province and Goyang-si of the Gyeonggi Province, which are both located north of Jeju, indicates that the species is more likely to use the country as their habitat. The purpose of this study is to report the progress of $P$. falcinellus observed in inland areas of South Korea in 2019 and to predict its region of origin and future propensity of inhabitation in the country through a study of foreign literature.

\section{Methods}

This study was conducted in a farmland located in Wolsanri, Hwayang-myeon, Seocheon-gun, South Chungcheong Province, and a site in Janghang-dong, Ilsandong-gu, Goyang-si, Gyeonggi Province. Wolsan-ri farmland (Fig. 1
(A)) is close to a two-lane Hwahan-ro in the southeast and a solar power plant in the southwest; however, it stretches about $400 \mathrm{~m}$ in the direction of the forest zone connecting to Gamtubong Peak. Except for farmers cultivating in the area, few people have access. Janghang-dong farmland (Fig. 1 (B)) is included in the Janghang wetland. The Janghang wetland stretches $7.6 \mathrm{~km}$ to Beopgot-dong, Ilsan Seo-gu, on the west and to Sinpyeong-dong, Deokyang-gu, on the east with a maximum width of $0.6 \mathrm{~km}$ and an area of $7.5 \mathrm{~km}^{2}$ (land $2.7 \mathrm{~km}^{2}$ and mudflats $4.8 \mathrm{~km}^{2}$ ). This wetland is rich in biodiversity and is composed of different types of habitats, including a variety of forest wetlands mainly consisting of a Salix subfragilis community, wet meadows with herbaceous plants, mudflats, and farmlands (Han et al. 2010, 2012; Yang et al. 2019). In recognition of this, the Janghang wetland was designated as a protected wetland area (Ministry of Environment Notice No. 200658) in 2006 and the EAAF Network site 143 (available on https://www.eaaflyway.net/rok/) in 2019.

As this study area was a type of open habitat, the bird survey employed a census methodology using telescopes and binoculars. Whenever nationally protected species (endangered wildlife, natural monument, and marine protected organism) or vagrants appeared, they were photographed or recorded using devices, such as smartphones and cameras.

\section{Results}

On 5 May 2019, one P. falcinellus appeared in the farmland of Wolsan-ri (Fig. 2). It had breeding feathers (Lee et al. 2018) with reddish-brown feathers on its head, neck, back, chest, and belly; moreover, it had glossy green and purple feathers on its upper wings. It slowly roamed in the middle of the farmland and used the pecking method of contacting the substrate with its bill to search for prey items. Then, it repeatedly picked up and put down the animal prey items with its bill before swallowing it. Furthermore, it obtained water from its bill to preen the feathers (Video S1). The following day, full-scale planting took place in the area, after which $P$. falcinellus was no longer observed. Twelve days later, on 17 May 2019, P. falcinellus appeared in the farmland of Janghang-dong, which was about $173 \mathrm{~km}$ north of Wolsan-ri (Fig. 2). Like the observations in Wolsan-ri, one individual with breeding feathers was spotted and it showed the same behavioral pattern. Shortly after the appearance of $P$. falcinellus, planting on the farmland of Janghang-dong was done, and the individual was no longer there.

\section{Discussion}

Commonalities between the two regions

There are a few commonalities in the observations of $P$. falcinellus in both areas in 2019. First, P. falcinellus is an 


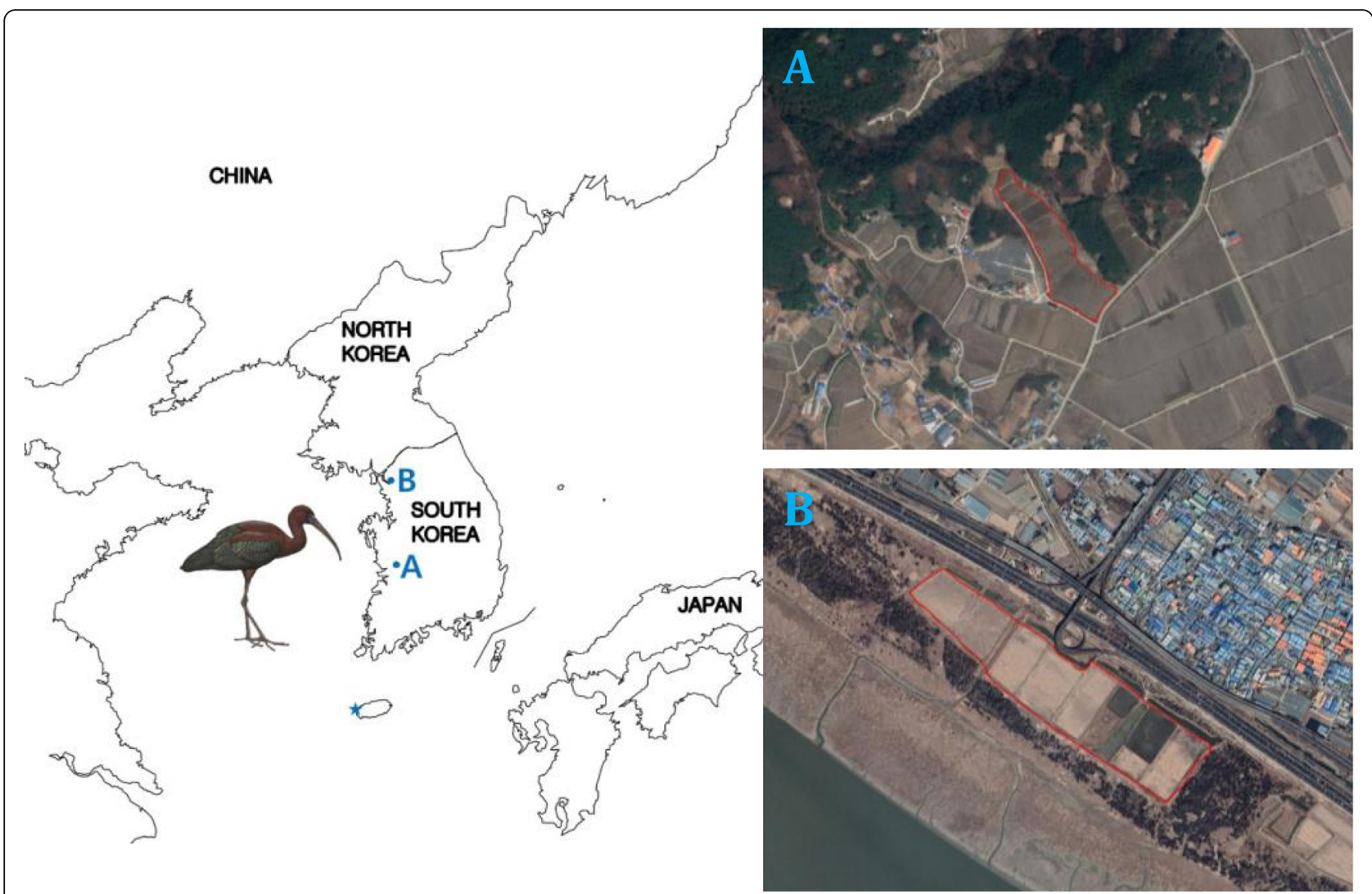

Fig. 1 Location map of the Glossy Ibis (Plegadis falcinellus) in South Korea in 2019: (a) Wolsan-ri rice field and (b) Janghang-dong rice field, based on the Google Earth satellite map. The distance between both areas was about $173 \mathrm{~km}$. The red line refers to the boundary of the foraging site of $P$. falcinellus in the area. The asterisk marks the region (Yongsu-ri, Jeju) where P. falcinellus appeared in 2018. Illustration of the P. falcinellus was provided free of charge in the Handbook of the birds of the world alive (del Hoyo et al. 2018)

opportunist species that uses a variety of strategies to obtain prey items, of which pecking and probing techniques using tactile sensation are commonly employed (Kushlan 1978; Trocki and Paton 2006). Their main prey items are aquatic insects and crustaceans, and they are known to feed on fish, amphibians, and occasionally reptiles (Hancock et al. 1992; Matheu and del Hoyo 1992). However, they tend to eat these animal diets mostly during the breeding periods when energy and nutritional requirements are high (Kushlan 1981; Acosta et al. 1996). The fecal analysis of adults using 15 P. falcinellus nests in 2000 and 36 vomits of fledglings just before leaving their nests in 2001 revealed that they were varying types of animal diets (Macias et al. 2004). In addition, analyses of prey items of chicks conducted in 2004, 2005, and 2007 found that animal diets were predominant (Nedjah et al. 2019). P. falcinellus individuals were all observed in May, and the months from April to
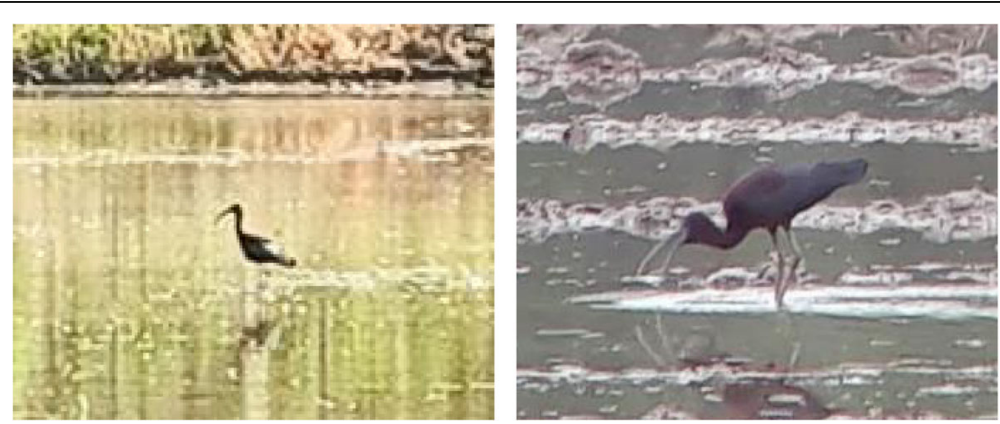

Fig. 2 The Glossy Ibis (Plegadis falcinellus) appeared in Worlsan-ri rice field on May 5, 2019 (left). It was spotted at the Janghang-dong rice field on May 17, 2019 (right) 
June are the migration and breeding season for birds inhabiting and arriving in South Korea (NIE 2019); thus, it is believed that they mainly fed on animal diets in the areas. Second, both areas are farmlands irrigated before planting. By the time of the arrival of waders, such as $P$. falcinellus, most rice paddies in the country have already been irrigated and farming activities, such as plowing, have taken place, forming various types of physical structures and providing important foraging sites for the species (Choi et al. 2014; Nam and Kim 2017). For $P$. falcinellus, which was in need of animal diets, the farmlands were the optimal places for eating them. Third, both areas are located in the western part of the country and are adjacent to the mouth of major rivers. The Wolsan-ri farmland is separated by about $2 \mathrm{~km}$ from the waterfront area at the mouth of the Geumgang River, and the Janghang-dong farmland is next to the mouth of the Han River. Western South Korea has $83 \%$ of the country's total mudflats as well as a variety of wetland environments, including major river estuary, farmland, and reservoirs, which are home to a wide variety of benthos (Park et al. 2007). The case of P. falcinellus, which appeared in Jeju in 2018, also shows geographic commonality in that Yongsu-ri, Hangyeong-myeon, is a wetland adjacent to the west coast of Jeju, although it is an island separate from the inland area. Finally, only one individual with breeding feathers was found and the duration of stay in the areas was 1 day. Given the distance between the two areas and the difference in the dates of each spotting, it is highly probable that it was the same individual, even though no ringing was done. In conclusion, $P$. falcinellus, which appeared in the inland areas of South Korea in 2019, is believed to have been around farmlands and wetlands distributed in the western part of the country. The pattern is different from the month ranging from mid-April to mid-May 2018, when its activity was limited to a narrow area of wetlands of Yongsu-ri and Yongdang-ri, Hangyeong-myeon, Jeju (Kang et al. 2019).

\section{Why did they disperse to South Korea?}

Dispersal of birds can be used as important data for studies on the population structure and dynamics of the species, behavioral ecology research, and the development of conservation strategies (Clobert et al. 2012). It is typically determined by a variety of internal factors, including age, gender, and body condition, and can be distinguished by external factors, such as social status, climate, and habitat environment change (Figuerola 2007; Clobert et al. 2012). P. falcinellus has the greatest dispersal capability of any bird species (Patten and Lasley 2000). An individual born in the Spanish Donãna National Park was observed in the Bermudas and Trinidad, about $6000 \mathrm{~km}$ away across the Atlantic Ocean (Santoro et al. 2013). The populations inhabiting North America were formed by the European populations that had crossed the Atlantic Ocean (Oswald et al. 2019). Judging from their dispersal abilities, the fact that the appearance of $P$. falcinellus had no observable record of the species in South Korea, but often observed in Japan and China adjacent to South Korea, can be seen as a natural event. However, it is necessary to infer the fundamental cause of the arrival of P. falcinellus in the country. According to the recent study, drought has been cited as a cause of their recent dispersal. Drought is a known determinant of breeding of water birds (Santoro et al. 2013). In the case of ibises, the mortality rate of the fledglings increases as adults give up breeding nests during drought (Kingsford and Johnson 1998). Among the ibis species, $P$. falcinellus is sensitive and vulnerable enough to skip breeding in severe droughts. In fact, populations living in the Spanish Donãna National Park did not reproduce in 1999 and 2005 when severe droughts occurred (Toral et al. 2012). In addition, $P$. falcinellus was reported to leave the area, where it was originally breeding in catastrophic drought, and form a population in a new area (Santoro et al. 2013).

P. falcinellus, which appeared in South Korea in 2018 and the following year, is highly likely to be from a population coming from Southeast Asia, which is one of the most important breeding grounds in the world (Matheu and del Hoyo 1992), and is the closest to South Korea in terms of distance, among all the regions located on the East Asian-Australasian Flyway (EAAF). Furthermore, droughts in Southeast Asia have been serious over the past few decades, including 2019, when P. falcinellus first appeared in South Korea. According to a report published by the UNESCAP (2019), drought in Southeast Asia over the past three decades has been caused by declining precipitation due to the El Niño phenomenon. The report added that unless nations do not take countermeasures, the areas affected by drought will expand by 2050 to include the northern parts of Southeast Asia, including Vietnam, Cambodia, and Thailand; moreover, the rate of droughts in Java, Indonesia, will increase from 62 to $72 \%$. If $P$. falcinellus observed in South Korea indeed came from Southeast Asia, it could be related to the sustained drought in the region. However, the odds of it arriving from the Australian region cannot be entirely ruled out. The Australian population of $P$. falcinellus is observed in freshwater wetlands and coastal areas throughout the country, with the core breeding ground being the MurrayDarling Basin located in the state of New South Wales. Over the past 230 years since European settlement, more than $50 \%$ of the wetlands in Australia have disappeared due to the water level control and drainage installations (Finlayson and Rea 1999). The dams built in the MurrayDarling river have changed the flow of water, posing a 
grave threat to the maintenance of the wetland environment that $P$. falcinellus favor (Brandis et al. 2011). Most of all, in 2019, Australia witnessed high temperatures and the lowest humidity and precipitation on record, causing a wildfire that began in New South Wales in September, which spread across the country (AGBM 2019). Although $P$. falcinellus is known to be an indigenous species of Australia (Marchant and Higgins 1990), there is a real possibility that it will risk a long-distance travel to settle elsewhere, given that some of these wader species, such as shorebirds, have arrived in South Korea flying from the Oceanian continent, including Australia (Park et al. 2013). However, the P. falcinellus that arrived in South Korea in 2018 and the following year cannot be identified as the same individual; thus, further studies with ringing to mark individual birds or movement tracking studies with attached transmitters will be required.

\section{Inference of inhabitation propensity in South Korea}

P. falcinellus, which arrived in South Korea in 2018 and the following year, came during the spring season and did not attempt to breed. If it continues to arrive in the future, it may appear only during spring, or it may show different inhabitation propensities. Among them, it is likely to show a different propensity for breeding. $P$. falcinellus, which occasionally nests in emergent vegetation, such as Phragmites connunis and Typha orientalis, but generally nests in shrubs and trees separated from the ground (Davis Jr. and Kricher 2000), breeds more with other kinds of water birds, especially egrets and herons, rather than breeding within a single colony (Marchant and Higgins 1990; Amezian et al. 2012; Nefla et al. 2012; Grussu 2019; Iankov and Popgeorgiev 2019; Nedjah et al. 2019; Onmuş and Karauz 2019; Sultanov 2019; Vera et al. 2019). The NIER (2012) data, which summarize the status of egrets and herons in South Korea through literature and field studies, record 174 breeding grounds of egrets across the country, most of which are located in areas linked to human activities. Although $P$. falcinellus is sensitive to human interference during the breeding season (Nedjah et al. 2019), it is likely to enter the local breeding grounds of egrets and herons and reproduce in a mixed way. Moreover, it arrived in 2019 for the first time in Hanzhong, Shaanxi, where there was no record of observation before and even reproduced in a region close to South Korea (available on https://news.cgtn.com/news/2019-07-25/Rareglossy-ibis-eggshells-found-in-NW-China-IBRMov4 A9O/index.html). This raises expectations for its breeding in South Korea. Another potential inhabitation propensity type is that autumnal migratory bird's exhibit. $P$. falcinellus shifted to plant diets, especially fallen rice grains during non-breeding periods, unlike the breeding period, when it relies on animal diets (Taylor and
Schultz 2010; Toral et al. 2012). Counting populations in agricultural areas in the Sancti Spiritus region of Cuba by breeding and non-breeding periods has resulted in a greater concentration of populations during the nonbreeding season (217 individuals/ha) compared to the breeding season (1.4 individuals/ha). This result is supported by the significant amount of grit entering body in the process of digesting fallen rice grains in the nonbreeding season. In fact, fallen rice grains were found in the stomach of a P. falcinellus found in February 1995 in Louisiana, USA (Acosta et al. 1996). In South Korea, a large number of ducks, geese, and cranes started arriving in the fall season and fed mostly on fallen rice grains obtained from farmland after harvest. Thus, if the path of $P$. falcinellus for spring and fall migration is the same, they could feed on fallen rice grains from farmland.

\section{Recommendation of effective survey system}

$P$. falcinellus has prominent reddish-brown, glossy green, and purple feathers (Lee et al. 2018). Due to its continued use of agricultural land (Matheu and del Hoyo 1992; Hancock et al. 1992; Taylor and Schultz 2010), there is no particular difficulty in identifying them. However, when they appeared, there should be a periodic survey system that can effectively detect their presence. South Korea has been conducting the National Ecosystem Survey for more than 30 years since 1986, a survey which spans the whole country to identify the distribution and status of biodiversity components for efficient management of national land (NIE 2019). The National Ecosystem Survey, which began its fifth round in 2019, sought to move away from the conventional biospecies inventory-based survey system in order to focus on habitat type-specific surveys and to avoid focus on only parts of habitat types. In addition, it used to be carried out only by professional experts; thus, it was not able to raise public awareness on the importance of the ecosystem. Many countries are expanding the application of citizen science to collect results by utilizing citizens' contribution. The 5th National Ecosystem Survey also aimed to introduce such type of citizen science (NIE 2019). In fact, P. falcinellus that was observed in the Janghang-dong farmland in 2019 was confirmed by citizen's scientific monitoring.

\section{Conclusions}

P. falcinellus is the most common species of SIS-SG, but it is one of the few species with an expanding distribution area (Gopi-Sundar and Cano-Alonso 2019). Furthermore, with extreme climate change events taking place globally, it has demonstrated excellent dispersal ability and ecological flexibility (Santoro 2019), indicating the necessity for an ecological study on P. falcinellus.

As for South Korea, the Crested Ibis (Nipponia nippon), which was extinct in 1979, drew national attention 
when 40 individual birds were released on May 22, 2019, by a restoration project started from a donation obtained from China in 2008 (available on http://www.cng.go.kr/ tour/ibis.web). At the same time, two consecutive years of identifying P. falcinellus, an ibis species that has not been recorded in the past in South Korea, serves as an encouraging event for further research. It will be interesting to observe whether this will end up as a fragmentary phenomenon without further effect or if it will turn South Korea into a region with a new metapopulation of $P$. falcinellus with its continuous appearance.

\section{Supplementary information}

Supplementary information accompanies this paper at https://doi.org/10 1186/s41610-020-00162-x.

Additional file $\mathbf{1}$ : Video S1. Glossy lbis (Plegadis falcinellus) in

Seocheon-gun foraging and preening on May 5, 2019.

\section{Acknowledgements}

We thank Yoon-Joo Choi of the Han River Basin Environmental Office and Pyung-Soo Park of the Goyang Citizen's Solar Power Coop for providing photo material as a citizen scientist.

\section{Authors' contributions}

$\mathrm{DH}$ and JYC carried out the field survey. SYL and HCS conducted the relevant reference study. SYL drafted the manuscript. HCS, DH, and JYC reviewed/edited the manuscript draft. $\mathrm{DH}$ and JYC made equal contributions to this study. All authors have read and approved the final manuscript.

\section{Funding}

This research was supported by the fifth National Ecosystem Survey (NIE-A2020-01) in the National Institute of Ecology (NIE) funded by the Ministry of Environment (MOE) of South Korea.

\section{Availability of data and materials}

The photo and video generated during the current study are available from the corresponding author on reasonable request.

\section{Ethics approval and consent to participate}

Not applicable.

\section{Consent for publication}

Not applicable.

\section{Competing interests}

The authors declare that they have no competing interests.

\section{Author details}

${ }^{1}$ Division of Ecological Survey, National Institute of Ecology, 1210, Geumgang-ro, Maseo-myeon, Seocheon 33657, South Korea. ${ }^{2}$ School of Biological Sciences and Biotechnology, Chonnam National University, Gwangju 61186, South Korea. ${ }^{3}$ PGA Eco and Bio Diversity Institute, Eco Korea, 139-43, Daeju-ro 107beon-gil, Deogyang-gu, Goyang 10456, South Korea.

Received: 5 March 2020 Accepted: 13 July 2020

Published online: 28 July 2020

\section{References}

Acosta M, Mugica L, Mancina C, Ruiz X. Resource partitioning between Glossy and White Ibis in a rice field system in southcentral Cuba. Colonial Waterbirds. 1996;19:65-72.

AGBM. Special climate statement 72-dangerous bushfire weather in spring 2019. Melbourne: AGBM; 2019.
Amezian M, El Khamlichi R, Elbanak A. Breeding of Glossy Ibis Plegadis falcinellus in the mixed heronry adjacent to Smir marshes, northern Morocco. Alauda. 2012;80:33-8.

Birdlife International. Species factsheet: Plegadis falcinellus. http:/www.birdlife.org; 2019. Accessed 22 Dec 2019.

Brandis KJ, Kingsford RT, Ren S, Ramp D. Crisis water management and Ibis breeding at Narran lakes in arid Australia. Environmental Management. 2011; 48(3):489-98.

Brazil M. Birds of East Asia: China. Taiwan: Korea, Japan, and Russia. New Jersey, Princeton University Press; 2009.

Champagnon J, Kayser Y, Petit J, Marion L, Reeber S, Rodriguez-Perez H, Blanchon T, Hilaire S, Badone I, Crouzier P, Purenne R, Gauthier-Clerc M. The settlement of Glossy lbis in France. SIS Conservation. 2019;1:50-5.

Choi SH, Nam HK, Yoo JC. Characteristics of population dynamics and habitat use of shorebirds in rice fields during spring migration. Korean J Environ Agric. 2014;33(4):334-43.

Clobert J, Baguette M, Benton TG, Bullock JM. Dispersal ecology and evolution. Oxford: Oxford University Press; 2012.

Davis WE Jr, Kricher JC. Glossy Ibis (Plegadis falcinellus). In: Poole AF, Gill FB, editors. The birds of North America (v 2.0). New York: Ithaca Press; 2000.

del Hoyo J, Elliott J, Sargatal DA, Christie DA, de Juana E. Handbook of the birds of the world alive (Eds.). Barcelona: Lynx Edicions; 2018.

Eaton JA, van Balen S, Brickle NW, Rheindt FE. Birds of the Indonesian archipelago: Greater Sundas and Wallacea. Barcelona: Lynx Edicions; 2016.

Figuerola J. Climate and dispersal: Black-Winged Stilts disperse further in dry springs. PLoS One. 2007;2:1-4.

Figuerola J, Mánez M, Ibáñez F, Garcia L, Garrido H. Morito común Plegadis falcinellus. In: Madroño A, González C, Atienza JC, editors. Libro Roojo de la aves de España. Madrid: SEO/Birdlife; Dirección General para la Biodiversidad; 2004

Finlayson CM, Rea N. Reasons for the loss and degradation of Australian wetlands. Wetlands Ecol Manag. 1999;7(1-2):1-11.

Gill F, Donsker D. IOC world bird list (v 9.2). 2019. http://www.worldbirdnames. org/; Accessed 10 Jan. 2020

Gopi-Sundar KS, Cano-Alonso LS. Editorial: A new publication focusing on storks, ibis, spoonbills and shoebill. SIS Conservation. 2019;1:6-7.

Grussu M. The breeding and wintering of Glossy lbis Plegadis falcinellus in Sardinia (Italy). SIS Conservation. 2019:1:21-6.

Hagemeijer EJM, Blair MJ. The EBCC (European Bird Census Council) Atlas of European breeding birds: their distribution and abundance. London: $T \& A D$ Poyser; 1997

Han D, Yang D, Lee EJ, Park S. Food web structure in a Salix subfragilis dominated wetland in Hnagng estuary using stable isotopes and fatty acid biomarkers. Anim Cells Syst. 2012;16:162-71.

Han D, Yoo JW, Yoo Y, Lee EJ, Park S. Aboveground primary productivity of Salix nipponica and secondary productivity of Sesarma dehaani at Janghang Wetland in Han River Estuary. Korean J Ecol Environ. 2010;43:298-306.

Hancock JA, Kushlan JA, Kahl MP. Storks, ibises and spoonbills of the world. New York: Academic Press; 1992.

lankov P, Popgeorgiev G. Breeding status of the Glossy Ibis Plegadis falcinellus in Bulgaria. SIS Conservation. 2019;1:56-9.

Kang CW, Kim EM, Park JY, Kim HJ, Hwang JW, Kang HM, Lee YS. First record of the Glossy Ibis (Plegadis falcinellus) in the Republic of Korea. Korean J Ornithol. 2019;26(1):26-8.

Kim YH, Kim WB, Oh HS. The distribution of Black Paradise Flycatcher on Jeju Island and management. Korean J Ornithol. 2011;18(2):141-8.

Kingsford RT, Johnson W. Impact of water diversions on colonially-nesting waterbirds in the Macquarie Marshed of arid Australia. Colonial Waterbirds. 1998:21(2):159-70.

Kushlan JA. Feeding ecology of wading birds. In: Sprunt A, Ogden JC, Winckler S, editors. Wading birds. New York: National Audubon; 1978.

Kushlan JA. Resource use strategies of wading birds. Wilson Bull. 1981;93:145-63.

Lee WS, Choi CY, Kim H. Field guide to the waterbirds of Asean. Seoul: AseanKorea Environmental Cooperation Unit; 2018.

Macias M, Green AJ, Sanchez MI. The diet of the Glossy lbis during the breeding season in Doñana, southwest Spain. Waterbirds. 2004;27:234-9.

Marchant S, Higgins PJ. Handbook of Australian, New Zealand and Antarctic birds: volume 1 ratites to ducks. Oxford: Oxford University Press; 1990.

Matheu E, del Hoyo J. Family Threskiornithidae (Ibises \& Spoonbills). In: del Hoyo J, Elliott A, Sargatal J, editors. Handbook of the birds of the world ( $v 1.0$ ). Barcelona: Lynx Edicions; 1992. 
Miyajima H, Takehara K, Tanaka K. A record of Glossy Ibis Plegadis falcinellus in Okinawa Prefecture, Japan. Japanese J Ornithol. 2015;64(2):267-70.

Morita Y, Koshino K, Yamawashi J. A record of Glossy Ibis on Tokashiki Island, Okinawa. Bird Res. 2014;10:23-4.

Nam HK, Kim MH. Determinations of shorebirds diets during spring migration stopovers in Korean rice fields. Korean J Environ Biol. 2017;35(4):452-60.

Nedjah R, Boucheker A, Touati L, Samraoui F, Samraoui B. Ecology and conservation of Glossy Ibis in Algeria: synthesis and perspectives. SIS Conservation. 2019;1:39-42

Nefla A, Ouni R, Nouira S. The breeding status of the Glossy Ibis Plegadis falcinellus in the Lebna Dam in Cap Bon, Tunisia. J Life Sci. 2012;6:776-82.

Nefla A, Ouni R, Nouira S. Past and present: the Glossy Ibis Plegadis falcinellus in Tunisia. SIS Conservation. 2019;1:16-20.

NIE. The fifth National Ecosystem Survey Protocols. Seocheon: NIE; 2019.

NIER. Egrets and herons in Korea. Incheon: NIER; 2012.

Oh HS, Kim YH, Chang MH, Kim TU, Park SG. Summer avifauna in Mum Islet, Sugwipo City, Jeju Special Self-Governing Province. Korean J Ornithol. 2010; 17(1):21-6.

Onmuş O, Karauz S. Historical and current status of Glossy Ibis Plegadis falcinellus in Turkey. SIS Conservation. 2019;1:90-7.

Oswald JA, Harvey MG, Remsen RC, Foxworth DU, Dittmann DL, Cardiff SW, Brumfield RT. Evolutionary dynamics of hybridization and introgression following the recent colonization of Glossy lbis (Aves: Plegadis falcinellus) into the new world. Mol Ecol. 2019;28(7):1675-91.

Park JY, Park JG, Choi CY. A photographic guide to the shorebirds of Korea. Seoul: Econature; 2013.

Park YS, Lee WS, Nam HK, Lee K, Yoo JC. Patterning waterbirds occurrences at the western coastal area of the Korean Peninsula in winter using a selforganizing map. Korean J Environ Biol. 2007;25(2):149-57.

Patten MA, Lasley GW. Range expansion of the Glossy Ibis in North America. North Am Birds. 2000;54:241-7.

Rodríguez JP. Welcome to Stork, Ibis and Spoonbill conservation. SIS Conservation. 2019;1:5.

Santoro S. Guest editorial. SIS Conservation. 2019;1:8-9.

Santoro S, Green AJ, Figuerola J. Environmental instability as a motor for dispersal: a case study from a growing population of Glossy Ibis. PLoS One. 2013;8:e82983 1-12.

Santoro S, Green AJ, Figuerola J. Immigration enhances fast growth of a newlyestablished source population. Ecology. 2016;97:1048-57.

Sultanov E. The Glossy Ibis Plegadis falcinellus in Azerbaijan. SIS Conservation. 2019:1:10-5.

Taylor IR, Schultz MC. Waterbird use of rice fields in Australia. Waterbirds. 2010;33: 71-82.

Thévenot M, Vernon R, Bergier P. The birds of Morocco: an annotated checklist (BOU checklist series No. 20). Tring: Natural History Museum; 2003.

Toral GM, Stillman RA, Santoro S, Figuerola J. The importance of rice fields for Glossy lbis (Plegadis falcinellus): management recommendations derived from an individual-based model. Biol Conservation. 2012;148(1):19-27.

Trocki CL, Paton WC. Comparison of two foraging habitats used by Glossy Ibis during the breeding season in Rhode Island. Northeastern Nat. 2006;13(1): 93-102.

UNESCAP. Ready for the dry years: building resilience to drought in South-East Asia. Bangkok: United Nations 2020; 2019.

Vera P, Forti M, Monrós JS. First insights into the Glossy Ibis Plegadis falcinellus population dynamics in l'Albufera de Valéncia (eastern Spain). SIS Conservation. 2019;1:127-34

Yang D, Han D, Park S. Intraspecific diet shifts of the sesarmid crab, Sesarme dehaani, in three wetlands in the Han River Estuary, South Korea. J Ecol Environ. 2019:43:6.

Zwarts L, Bijlsma RG, van der Kamp J, Wymenga E. Living on the edge: wetlands and birds in a changing Sahel. Zeist: KNNV Publishing; 2009

\section{Publisher's Note}

Springer Nature remains neutral with regard to jurisdictional claims in published maps and institutional affiliations.

\section{Ready to submit your research? Choose BMC and benefit from:}

- fast, convenient online submission

- thorough peer review by experienced researchers in your field

- rapid publication on acceptance

- support for research data, including large and complex data types

- gold Open Access which fosters wider collaboration and increased citations

- maximum visibility for your research: over $100 \mathrm{M}$ website views per year

At BMC, research is always in progress.

Learn more biomedcentral.com/submissions 